\title{
Letter from the Editor-in-Chief: Real options and international business
}

\section{Lorraine Eden}

Journal of International Business Studies (2009) 40, 357-360.

doi: $10.1057 / j i b s .2008 .107$
Volume 40.3 consists of eight articles accepted for publication by former JIBS Editor-in-Chief Arie Y. Lewin, together with a Letter from the Editors and a Research Note accepted under my watch.

The Letter from the Editors, "Student Samples in International Business Research," by Bello, Leung, Radebaugh, Tung, and van Witteloostuijn, discusses the pros and cons of student samples in international business (IB) research. The JIBS Statement of Editorial Policy states that "Empirical submissions utilizing undergraduate student samples are usually discouraged." This editorial is designed to provide IB researchers with guidelines as to when and what types of student samples are appropriate in IB research.

While each of the pieces in this issue makes important contributions to our knowledge of IB studies, the articles using real options theory to analyze multinational enterprise (MNE) decision-making under uncertainty may be of particular interest to IB researchers.

\section{REAL OPTIONS AND IB}

Real options theory has been an important lens for understanding MNE strategic decision-making since the seminal articles by Kogut (1984, 1991) and Kogut and Kulatilaka (1994). Kogut's first article, published 25 years ago in JIBS, is remarkably prescient as a predictor of current IB research in this area:

\footnotetext{
For the firm which can achieve flexibility to shift production, marketing segments, or product lines rapidly, fluctuations in these variables become a source of strategic advantage over the competition .... . [A] multinational network provides the strategic advantage of responding to shifts in real economic costs. One of the key strengths of the multinational corporation is its capability to respond to environmental variance. (Kogut, 1984: 161-162)
}

A search of the JIBS archives using real options keywords reveals that more than two dozen articles using this theoretical framework have been published in JIBS, with the most common topics being those identified in Kogut (1984): capital structure, valuation of the MNE network, and strategic decision-making (e.g., location, mode of entry, and timing of entry decisions). Several of these articles, together with other classics in real options theory, can be found in Rugman and Li (2005).

Perhaps the most extensive application of real options theory in the IB literature has been to the mode of entry decision, particularly to international joint ventures (IJVs). The best known JIBS article on this topic is probably Buckley and Casson (1998a). 
In this piece, the authors argue for a "new dynamic agenda" that focuses on:

\begin{abstract}
uncertainty and market volatility; flexibility and the value of real options; co-operation through joint ventures and business networks; entrepreneurship, managerial competence and corporate culture; and organizational change, including the mandating of subsidiaries and the "empowerment" of employees. (ibid: 22)
\end{abstract}

As an example of this new, dynamic agenda, the authors explore modeling of the mode of entry decision from a dynamic rather than a static perspective, where the foreign market can either grow or decline and switching between strategies is costly. IJVs emerge as potentially preferable to either of the polar extremes of the external or internal market. IJVs both exploit and buffer the MNE from high environmental uncertainty by providing operational flexibility at relatively low cost. The authors' analysis of entry mode choice is, however, only outlined and not fully developed.

In the same 1998 JIBS volume, Buckley and Casson (1998b) do provide a fully developed analysis of entry mode choice, but the modeling is a comparative statics analysis, using internalization theory (transaction costs) as the theoretical lens. This article remains the classic statement, the benchmark against which other articles are compared, due to its careful and thorough comparisons of the benefits and costs to the MNE of 12 possible entry strategies.

Using real options as the theoretical lens to compare across multiple modes of entry, however, has been a lacuna in the IB literature. How do we dynamically model the entry mode decision under uncertainty where switching across modes is possible, but costs must be incurred in doing so? That lacuna has now been filled in JIBS 40.3 by Chi and Seth in "A dynamic model of the choice of mode for exploiting complementary capabilities." Their article integrates insights from Kogut (1991) and Buckley and Casson (1998a,b) with insights from dynamic capabilities and bargaining theories. The authors model two parties (the MNE and a local firm), where initial entry can either be a license, JV (greenfield or partial acquisition) or full acquisition. The entry mode can change over time, with the key "tipping point" variables being the evolution of firm capabilities and differences in absorptive capacities, frictions in the knowledge (tacitness of knowledge) and asset (asset inseparability) markets, bargaining problems, and switching costs. The authors simulate different scenarios and use dynamic programming with the software program MathCAD to address questions such as: Can both parties win a JV learning race? How does uncertainty affect JV viability? Is market failure a necessary condition for JV selection? When is acquisition or licensing superior to a JV? Can flexibility destroy as well as create value?

The Chi and Seth article offers IB scholars a rich foundation on which to build our knowledge of modes of entry. One direction that still needs pursuing, however, is the international or cross-border dimension since the concepts developed in their article also apply to entry mode choice when a firm makes a new investment at home. How do IJVs differ from JVs, using real options theory? What are the key differences between foreign and domestic market entries? Foreign market entries presumably raise the levels of all the tipping point variables identified by Chi and Seth, but by how much and in which direction? Which variables are more important for cross-border than within-country investments? Are the costs of knowledge and asset market frictions more important for foreign market entries than differences in the evolution of firm capabilities and absorptive capacities? What can we predict if the entrant is an emerging market firm exploring an IJV with a local developed market firm, or vice versa?

Some possible insights into these questions are provided by Puck, Holtbrügge, and Mohr in "Beyond entry mode choice: Explaining the conversion of joint ventures into wholly owned subsidiaries in the People's Republic of China." The authors use a comparative statics approach, drawing on insights from transaction cost economics and institutional theory, to explore why and when an IJV is converted into a wholly owned subsidiary (WOS). Key tipping point variables are acquisition of local knowledge by the MNE and isomorphic pressures from the MNE network. Switching to a WOS is less likely as external uncertainty, cultural distance and host-country regulatory complexity increase. The authors find support for these hypotheses from a 2006 survey of 94 foreign firms in China. This article nicely complements Steensma, Barden, Dhanaraj, Lyles, and Tihanyi (2008) in JIBS 39.3, who found that an IJV converts to a WOS only when there is both a power imbalance and high levels of conflict between the partner firms. High knowledge 
transfers from the MNE to the joint venture coupled with high conflict increase the likelihood of conversion to a WOS. While real options is not the theoretical lens in either article, both find variables identified in Chi and Seth to be important predictors of mode switching: uncertainty, power imbalances and conflicts, frictions in knowledge markets, and switching costs.

Lee and Makhija in "The effect of domestic uncertainty on the real options value of international investments" also provide a nice complement to Chi and Seth, using real options theory to explore the impacts of domestic economic and exchange rate uncertainty on MNE value. The authors hypothesize that higher domestic and international uncertainty should both negatively affect MNE firm value. Greater breadth and less depth in the MNE network (which the authors argue provides operational flexibility) should weaken these effects. Their empirical work, involving 270 Korean firms over 1990-2006, provides support only for the hypotheses involving domestic uncertainty. The authors argue that hedging may have mitigated the negative impacts of exchange rate uncertainty on firm value.

\section{OTHER HIGHLIGHTS IN JIBS 40.3}

Greater disclosure of geographic segments provides more information to stock market analysts about the breadth and depth of the MNE network. If greater breadth provides operational flexibility in volatile enviroments and increases firm value (as hypothesized by Lee and Makhija), one might expect the valuation of foreign earnings to be positively related to greater geographic segment disclosure by MNEs. Hope, Kang, Thomas, and Vasvari in "The effects of SFAS 131 geographic segment disclosures by US multinational companies on the valuation of foreign earnings" find that greater information disclosure does generate value because it reduces information asymmetry and lowers investors' risk premia. Moreover, the positive impact on foreign earnings increases with the number of geographic segments disclosed. The authors conclude that their results should be relevant to all MNEs with geographic breadth, not just US firms.

In "How do corporate governance model differences affect foreign direct investment in emerging economies?" Luo, Chung, and Sobczak analyze the decisions of US and Japanese MNEs to set up an IJV with a domestic partner firm in Taiwan. They find that home-country corporate governance and host-country family ownership are key predictors of the MNE choosing an IJV with a domestic partner. This article is an interesting complement to Puck, Holtbrügge, and Mohr, suggesting additional reasons why a foreign firm, after selecting an IJV, might be resistant to converting it to a WOS.

Three micro-level articles are included in this issue. Despite their proliferation, cross-border mergers and acquisitions often fail. Cross-cultural work alienation in the post-acquisition stage could be a primary cause of these failures, according to Brannen and Peterson in "Merging without alienating: Interventions promoting cross-cultural organizational integration and their limitations." Their paper is also interesting from a research methodology perspective because of its careful use of qualitative mixed methods for theory development (a 5-year ethnographic study and survey questionnaires).

Chua, Morris, and Ingram in "Guanxi vs networking: distinctive configurations of affect- and cognition-based trust in the networks of Chinese vs American managers" explore differences between Chinese and US managers in their social networks. The authors find that Chinese executive networks are strongly affected by the norm of familial collectivism; as a result, affect- and cognition-based trust are more likely to be intertwined in Chinese than US networks.

Reiche, Harzing, and Kraimer in "The role of international assignees' social capital in creating inter-unit intellectual capital: A cross-level model" argue that expats can be informational boundary spanners, facilitating knowledge transfers between MNE affiliates. The extent to which knowledge flows occur depends upon the assignees' social capital in both sending and receiving locations. This article is a useful complement to Oddou, Osland, and Blakeney (2009) and Furuya, Stevens, Bird, Oddou, and Mendenhall (2009) in JIBS 40.2.

The issue concludes with a provocative Research Note, which is likely to re-ignite the dialogue in the IB field on the validity of Hofstede's work on culture. In "Explaining the negative correlation between values and practices: A note on the Hofstede-GLOBE debate," Maseland and van Hoorn comment on the Hofstede-GLOBE debate that appeared in JIBS 37.6. 


\section{REFERENCES}

Buckley, P., \& Casson, M. 1998a. Models of the multinational enterprise. Journal of International Business Studies, 29(1): 21-44.

Buckley, P., \& Casson, M. 1998b. Analyzing foreign market entry strategies: Extending the internationalization approach. Journal of International Business Studies, 29(3): 539-561.

Furuya, N., Stevens, M. J., Bird, A., Oddou, G., \& Mendenhall, M. 2009. Managing the learning and transfer of global management competence: Antecedents and outcomes of Japanese repatriation effectiveness. Journal of International Business Studies, 40(2): 200-215.

Kogut, B. 1984. Normative observations on the international value-added chain and strategic groups. Journal of International Business Studies, 15(2): 151-167.
Kogut, B. 1991. Joint ventures and the option to expand and acquire. Management Science, 37(1): 19-33.

Kogut, B., \& Kulatilaka, N. 1994. Operating flexibility, global manufacturing, and the option value of a multinational network. Management Science, 40(1): 123-139.

Oddou, G., Osland, J., \& Blakeney, R. N. 2009. Repatriating knowledge: Variables influencing the "transfer" process. Journal of International Business Studies, 40(2): 181-199.

Rugman, A., \& Li, J. (Eds) 2005. Real options and international investment. Cheltenham: Edward Elgar.

Steensma, K., Barden, J., Dhanaraj, C., Lyles, M., \& Tihanyi, L. 2008. The evolution and internationalization of international joint ventures in a transitioning economy. Journal of International Business Studies, 39(3): 491-507. 